\author{
ACTA MYCOLOGICA \\ Vol. 46 (1): 3-18 \\ 2011
}

\title{
Arbuscular mycorrhizal fungi (Glomeromycota) associated with roots of plants of the Lubuskie province
}

\author{
SŁAWOMIR KOWALCZYK and JANUSZ BŁASZKOWSKI \\ Department of Plant Protection, West Pomeranian University of Technology \\ Słowackiego 17, 71-434 PL Szczecin, janusz.blaszkowski@zut.edu.pl
}

Kowalczyk S., Błaszkowski J.: Arbuscular mycorrhizal fungi (Glomeromycota) associated with roots of plants of the Lubuskie province. Acta Mycol. 46 (1): 3-18, 2011.

The results of studies of the occurrence of arbuscular mycorrhizal fungi (AMF) and arbuscular mycorrhizae of the phylum Glomeromycota associated with roots of 31 cultivated, uncultivated and protected plant species growing at 103 sites of the Lubuskie province NW Poland are presented and discussed. The AMF most frequently found were members of the genus Glomus. Other relatively frequently revealed fungi were Scutellospora spp. Spore populations of AMF generally were more abundant and diverse in cultivated soils. Most protected plant species harboured AMF.

Key words: distribution, occurrence, cultivated, wild and protected plants, Poland

\section{INTRODUCTION}

Arbuscular mycorrhizal fungi (AMF) of the phylum Glomeromycota (Schüßler, Schwarzott and Walker 2001) belong to the most widely distributed soil microorganisms in the world and are associated with ca. 70-90\% of vascular land plants (Smith, Read 2008). At present, the phylum Glomeromycota consists of four orders, 10 families and 14 genera (Oehl, Sieverding 2004; Palenzuela et al. 2008; Schüßler et al. 2001; Sieverding, Oehl 2006; Walker et al. 2007). The most numerous group within the Glomeromycota is the genus Glomus, comprising ca. 53\% of all species of the phylum known to date, i.e., ca. 220 (Błaszkowski 2003).

AMF are well known to increase productivity and vigour of plants, as well as their resistance to different abio- and biotic stresses (Schönbeck 1978; Koske et al. 2004). Additionally, AMF stabilize soils and improve their structure throughout binding sand grains and aggregate formation (Koske, Polson 1984). The effectiveness and stability of such influences are generally higher when AMF communities are more diverse (Bever et al. 1996; Klironomos et al. 2000). 
Asexual spores of AMF are persistent propagules that remain infectious in the absence of host plants and under unfafourable conditions, e.g., because of influences of different agricultural practices. On the other hand, different plant species and farming practices may variously affect the spore production of different species of AMF (Bever et al. 1996; Jansa et al. 2002; Oehl et al. 2009). Recognition of the reasons that mainly affect AMF may be used in constructing of crop rotations and farming practices to retain high vitality of this important group of soil microorganisms.

Most studies of AMF diversity rely on morphological identification of spores extracted either from field-collected soil samples or/and trap cultures in which field soils with appropriate host plants are grown in a greenhouse (Oehl et al. 2009). However, each of these techniques has constrains. Examination of field soils frequently reveals AMF that do not sporulate in trap cultures (Błaszkowski, pers. observ.). On the other hand, cultivation of field soils in trap cultures may initiate sporulation of fungi forming spores seasonally, rarely or not at all in field conditions (Błaszkowski, Kovács and Balázs 2009; Błaszkowski, Tadych and Madej 2000; Błaszkowski et al. 2009; Stutz, Morton 1996). An ideal method of recognizing of AMF associated with plant roots seems to be that using molecular tools. However, its high costs and labor, as well as the lack of specific molecular markers for most existing AMF also restrict their wide application (Öpik et al. 2009).

One of the main aims of numerous plant protection projects are the preservation and protection of rare and endangered plant species (Zubek, Turnau and Błaszkowski 2005). Most of these plants probably co-occur with AMF, although the amount of literature data on this subject is very low. The recognition of AMF most frequently co-existing with such plant species may be used to protect them by introduction of these fungi into sites where the plants grow.

In soils of the Lubuskie province, only one species of AMF has been found to date, i.e., Acaulospora thomii Błaszk. (Błaszkowski 1988). Therefore, the aim of this study was to better know AMF associated with roots of cultivated, uncultivated (not protected) and protected plants growing in soils of this region.

\section{MATERIALS AND METHODS}

The study material and area. The study material were mixtures of rhizosphere soils and roots collected under 31 cultivated, wild (not protected), and protected plant species growing at 103 sites located in the Lubuskie province (Fig. 1).

Collection of rhizosphere soils and roots, establishment and growth of trap cultures, extraction of spores, staining of mycorrhizae, and identification of AMF. Rhizosphere soils and root fragments were collected from May to August of the years 2003-2006. They were taken from a depth of 5-30 cm using a small garden shovel and then placed in plastic bags. In the laboratory, they were air dried and then stored in a refrigerator at ca. $4^{\circ} \mathrm{C}$ for $1-4$ months.

Trap cultures were established to obtain a large number of living spores and to initiate sporulation of species that were present but were not detected in the field collections (Stutz, Morton 1996). The method used to establish trap cultures, their 


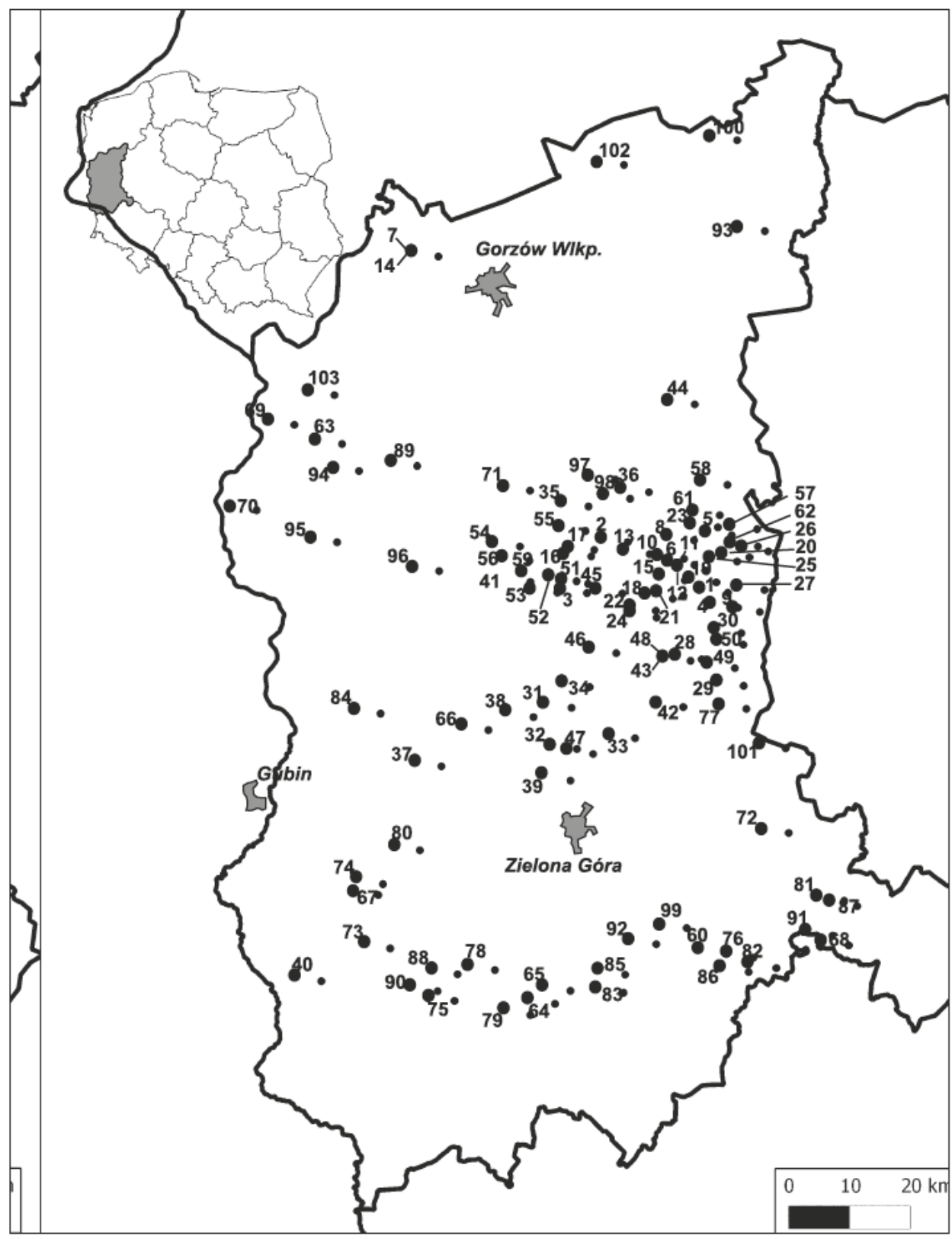

Fig. 1. Sites of collection of the rhizosphere soil and roots of cultivated, uncultivated (not protected), and protected plants in the Lubuskie province.

Cultivated plants. Asparagus officinalis L.:* 26; 27; Trzciel; Lutol Mokry; 25.04.2004; 25.05.2004; 43-45, 126-128; 46-48; Avena sativa L.; 4; 5; 6; 31; 32; 33; 72; 73; 74; Dąbrówka Wlkp.; Sierczynek; Łagowiec; Przetocznica; Brody; Mozów; Lipka; Jasień; Godno; 2.07.2003; 3.08.2003; 2.08.2003; 12.08.2004; -“-; -"-; 18.06.2005; -“--; -“-; 4; 5; 6; 57; 58; 59; 136; 137; 138; Brassica napus L.: 1; 6; 12; 15; 19; 64; 65; 66; 67; Rogoziniec; Lagowiec; Lutol Suchy; Brójce; Chociszewo; Jablonów; Wrzesiny; Radnica; Górzyn; 25.04.2004; -"-; -"-; -"-; -"-; 18.06.2005; -"-; -"-; -"-53; 51; 50; 49; 52; 129; 130; 131; 
132; Beta vulgaris L.: 1; 2; 3; 28; 29; 30; 68; 69; 71; Rogoziniec; Kaława; Nowa Wioska; Brudzewo; Babimost; Zbąszynek; Krzepielów; Żabice; Grochowo; 22.07.2003; 2.08.2003; -“-; 12.08.2004; -“-; -“-; 18.06.2005; 19.06.2005; -“--; 1; 2; 3; 54; 55; 56; 133; 134; 135; Hordeum vulgare L.: 1; 1; 7; 8; 29; 29; 34; 35; 75; 76; 77; Rogoziniec; -“-; Wysoka; Bukowiec; Babimost; -“-; Skąpe; Pieski; Lubomyśl; Różanówka; Leśniki; 22.07.2003;-“-;2.08.2003;3.08.2003; 12.08.2004;-“--;-“-; 12.08.2004; 18.06.2005; -“-; -“-; 1; 7; 8; 9; 55; 61; 60; 62; 139; 140; 141; Secale cereale L.: 9; 10; 11; 36; 37; 38; 78; 79; 80; Samsonki; Stary Dwór; Lutol Suchy (st. kolejowa); Międzyrzecz; Połupin; Sycowice; Gorzupia; Dzietrzychowice; Dęby; 22.07.2003; 2.08.2003; 3.08.2003; 12.08.2004; -“-; -“-; 18.06.2005; 18.06.2005; -“-; 10; 11; 12; 63; 64; 65; 142; 143; 144; Solanum tuberosum L.: 4; 40; 47; 48; 49; 50; 90; 91; 92; Dąbrówka Wlkp.: Łazy; Pomorsko; Smardzewo; Podmokle Małe; Kosieczyn; Surowa; Krążkowo; Wrociszów; 12.08.2004; -“--; -“-; -“-; -“-; -“--; 18.06.2005; -“-; -“-; 80; 75; 76; 77; 78; 79; 154; 155; 156; Triticum aestivum L.: 8; 10; 14; 15; 32; 32; 39; 81; 82; 83; Bukowiec; Stary Dwór; Wysoka; Brójce; Brody; -“-; Czerwieńsk; Jutrzenka; Kierzno; Styrułów; 12.08.2004; 2.08.2003; -“-; 3.08.2003; 12.08.2004; -“-; -“-; 18.06.2005; 18.06.2005; -“-; 66; 17; 16; 18; 58; 68; 67; 145; 146; 147; XTriticose-cale Wittmack: 12; 13; 41; 42; 43; 84; 85; 86; Lutol Suchy; Szumiąca; Lagów (k/Gronowa); Łęgowo; Smardzewo; Lubogoszcz; Podbrzeże; Dębianka; 22.07.2003; 2.08.2003; 12.08.2004; -“-; -“-; 18.06.2005; -“-; -“-; 13; 14; 69; 70; 71; 148; 149; 150; Zea mays L.: 16; 17; 18; 44; 45; 46; 87; 88; 89 Staropole; Boroszyn; Myszęcin; Przytoczna; Rubinów; Chociule; Stare Strącze; Bieniów; Drogomin; 2.08.2003; -“-; -“-; 11.08.2004; 12.08.2004; -“-; 18.06.2005; -“-; 19.06.2005; 19; 20; 21; 72; 73; 74; 151; 152; 153.

Uncultivated (not protected) plants. Achillea millefolium L.: 2; 19; 20; 51; 52; 53; Kaława; Chociszewo; Jasieniec; Lubrza; Romanówek; Bucze; 2.08.2003; 22.07.2003; 2.08.2003; 13.08.2004; -“-; -“-; 23; 22; 24; 81; 82; 83; Cirsium arvense L.: 21; 22; 23; 51; 54; 55; Wilenko; Wityń; Żydowo; Lubrza; Jemiołów; Zarzyń; 3.08.2003; -“-; 3.08.2003; 13.08.2004; -“-; -“-; 25; 26; 27; 84; 85; 86; Melandrium album L.: 51; 52; 56; Lubrza; Romanówek; Łagów; 13.08.2004; -“-;-“-; 87; 88; 89; Sedum maximum (L.) Hoffm.: 26; 26; 51; 59; 95; 96; 97; Trzciel; -“-; Lubrza; Żelechów; Rzepin; Torzym; Górzyce; 3.08.2003; 15.08.2004; -“-; -“-; 19.06.2005; -“-; -“-; 32; 95; 81; 94; 161; 160; 162; Carex sylvatica Huds: 57; 58; 93; 94; 95; Rybojady; Borowy Młyn; Drezdenko; Ośno Lubuskie; Rzepin; 15.08.2004; -“-; 18.06.2005; 19.06.2005; -“-; 90-91; 92; 157; 158; 159; Equisetum arvense L.: 5; 25; 26; 55; 56; 57; Sierczynek; Bieleń; Trzciel; Łagów; Rybojady; 3.08.2003; -“-; 3.08.2003; 13.08.2004; -“-; -“-; 33; 31; 32; 96; 97; 98; Trifolium arvense L.: 2; 53; 54; 64; 70; 98; Kaława; Bucze; Jemiołów; Jabłonów; Drzecin; Jagielniki; 12.08.2004; 13.08.2004; -“-; 18.06.2005; 19.06.2005; 18.06.2005; 99; 100; 101; 164; 163; 165; Hypericum perforatum L.: 51; 52; 54; 96; 99; 100; Lubrza; Romanówek; Jemiołów; Torzym; Nowa Sól; Dobiegniew; 13.08.2004; -“-; -“-; 19.06.2005; 18.06.2005; 19.06.2005; 102; 103; 104; 168; 166; 167; Juncus effusus L.: 26; 56; Trzciel; Łagów; 15.08.2004; 21.06.2005; 105-107; 169-171; Plantago arenaria Waldst. et Kit.: 26; 26; Trzciel; -“-; 15.08.2004; 22.06.2005; 108-110; 172-174; Plantago lanceolata L.: 16; 20; 23; 54; 57; 60; Staropole; Jasieniec; Żydowo; Jemiołów; Rybojady; Siedlisko; 2.08.2003; 3.08.2003; -“-; 13.08.2004; -“-; -“-; 34; 35; 36; 113; 111; 112; Corynephorus canescens (L.) P. Beauv.: 26; 94; 101; 102; Trzciel; Ośno Lubuskie; Stary Jaromierz; Skólsko; 15.08.2004; 19.06.2005; 18.06.2005; -“-; 114-116; 176; 175; 177; Polygonum persicaria L.: 5; 13; 23; 58; 61; 62; Sierczynek; Szumiąca; Żydowo; Borowy Młyn; Siercz; Świdwowiec; 3.08.2003; 2.08.2003; 3.08.2003; 15.08.2004; -“-; -“-; 39; 37; 38; 117; 118; 119; Rumex acetosella L.: 4; 6; 17; 37; 52; 63; Dąbrówka Wlkp.; Łagowiec; Boroszyn; Połupin; Romanówek; Gronów; 22.07.2003; 2.08.2003; -“-; 12.08.2004; 13.08.2004; 12.08.2004; 40; 41; 42; 120; 122; 121; Potentilla anserina L.: 26; 103; Trzciel; Słońsk; 15.08.2004; 19.06.2005; 123-125; 178-180.

Protected plants. Vinca minor L.: 56; 56; Lagów; -“-; 21.06.2005; 24.06.2006; 217-218; 226-228; Hedera helix L.: 56; 56; Łagów; -“-; 13.08.2008; 21.06.2005; 211-213; 219-223; Helichrysum arenarium (L.) Moench: 26; 26; Trzciel; -“-; 3.08.2003; 15.08.2004; 181-185; 196-198; Jovibarba sobolifera (Sims.) Opiz: 26; 26; Trzciel; -“-; 3.08.2003; 15.08.2004; 186-190; 199-201; Convallaria majalis L.: 56; 56; 56; Łagów; -“-; -“-; 17.04.2004; 9.04.2005; 8.04.2006; 205-207; 214-216; 224-225; Lycopodium clavatum L.: 26; 26; Trzciel; -“-; 3.08.2003; 15.08.2004; 191-195; 202-204.

*After the plant species name, the number of location(s), the name of location(s), the date(s) of collection, and the number of samples are listed, respectively. 
growing conditions, and the methods of spore extraction and staining of mycorrhizae were as those described previously (Błaszkowski, Renker and Buscot 2006). The host plants were Plantago lanceolata and Zea mays.

Morphological properties of spores and their subcellular structure were determined based on examination of at least 50 spores mounted in water, lactic acid, polyvinyl alcohol/lactic acid/glycerol (PVLG; Omar, Bollan and Heather 1979), and a mixture of PVLG and Melzer's reagent (1:1, v/v). Spores at all developmental stages were crushed to varying degrees by applying pressure to the cover slip and then stored at $65^{\circ} \mathrm{C}$ for $24 \mathrm{~h}$ to clear their contents from oil droplets. They were then examined under an Olympus BX 50 compound microscope equipped with Nomarski differential interference contrast optics. Microphotographs were recorded on a Sony 3 CDD color video camera coupled to the microscope.

AMF were identified according to original descriptions, specimens collected by J. Błaszkowski, and descriptions and illustrations presented in Błaszkowski (2003) and Morton (2002).

Chemical and statistical analyses. For chemical analyses, 81 soil samples were selected, in which $\mathrm{pH}$ (in $1 \mathrm{~N} \mathrm{KCl}$ ), the contents of $\mathrm{N}, \mathrm{P}, \mathrm{K}$, organic $\mathrm{C}$ (in $\mathrm{gkg}^{-1}$ of dry matter), and available forms of $\mathrm{P}, \mathrm{K}$, and $\mathrm{Mg}$ (in $\mathrm{mgkg}^{-1}$ of dry matter) were determined. Each cultivated and uncultivated (not protected) plant species was represented by three randomly selected soil samples, and each protected plant species by one.

Differences in the structure of AMF communities were investigated by determining the frequency of occurrence of species, spore abundance and species richness, and by calculating dominance coefficients (Górny, Gruma 1981). Spore abundance and coefficients of dominance were determined based on spores isolated only from field-collected samples. Frequency of occurrence and species richness were calculated based on spores isolated from both field-collected samples and trap cultures. Frequency of occurrence was calculated by determining the percentage of fieldcollected samples and trap cultures from which spores of a particular species were recovered. Spore abundance and species richness were defined by determining the number of spores and species, respectively, occurring in 50 or $100 \mathrm{~g}$ dry soil. Dominance coefficient expresses the proportion of the number of spores of a particular species in all spores of AMF recovered.

Coefficients of correlation were used to determine relationships between the spore abundance and soil chemical properties.

\section{RESULTS AND DISCUSSION}

\section{ARBUSCULAR MYCORRHIZAL FUNGI AND ARBUSCULAR MYCORRHIZAE ASSOCIATED WITH CULTIVATED AND UNCULTIVATED (NOT PROTECTED) PLANTS}

Arbuscular mycorrhizal fungi. The occurrence of AMF in cultivated and uncultivated soils was determined based on spores isolated from field-collected rhizosphere soil-root samples and trap cultures established from a part of each field sample. The soil-root samples came from under 25 plant species belonging to 16 families (Fig. 1). 
Of them 10 were cultivated plant species, and the others uncultivated once, including medicine plants. Each cultivated plant species was represented by 9 soil-root samples, and uncultivated one by 6 .

A total of 40287 spores of AMF were isolated, including 11517 spores from field samples (of which $39.6 \%$ come from under cultivated plants) and 28770 spores from trap cultures. The spores represented 9 of the 14 exiting genera of the Glomeromycota (Tab. 1). Most species (18) were from the genus Glomus. The genus Acaulospora was represented by 5 species, and the genera Entrophospora, Gigaspora, Pacispora, and Scutellospora by 5 species each. One species each came from the genera Ambispora and Paraglomus. Additionally, not numerous spores of unrecognized species of the genera Gigaspora, Glomus, and Scutellospora were found.

Occurrence of AMF. Spores of AMF occurred in $92.8 \%$ of field-collected soil samples. They represented 13 species of Glomus, 5 of Acaulospora, 3 of Scutellospora, 2 each of Entrophospora, Gigaspora and Pacispora, and 1 of Ambispora (Tab. 1). In the root zone of cultivated plants, 15 species in three genera occurred. Roots of wild plants harboured 28 species in 7 genera and not numerous spores of unrecognized species of Glomus and Scutellospora. Of the AM fungal species identified in field soils, 21 sporulated in trap cultures (Tab. 1). Spores of Acaulospora capsicula, Ac. lacunosa, Ac. koskei, Ac. mellea, Entrophospora baltica, Gigaspora gigantea, and Glomus fuegianum were revealed only in field soils.

In trap cultures, 27 species and not numerous spores of unrecognized morphotypes were revealed.

The AMF most frequently occurring in the Lubuskie province soils were members of the genus Glomus (Tab. 1); they occurred in $87.2 \%$ of soils, of which $47.0 \%$ represented cultivated plants. Glomus spp. were associated with all plant species of the families Asteraceae, Caryophyllaceae, Cyperaceae, Equisetaceae, Hyperiaceae, and Polygonaceae. Other relatively frequently revealed AMF were Scutellospora spp. (more frequently co-occurred with most families of uncultivated plants) and Pacispora spp. (were more frequently harboured by families of cultivated plants).

Members of the genera Acaulospora, Ambispora, Gigaspora, and Paraglomus were recorded only in soils from under uncultivated plants (Tab. 1).

The disclosure of 10 species and one undescribed morphotype in trap cultures that were not found in field soils confirms conclusions of, e. g., Błaszkowski, Tadych and Madej (2002), Stütz \& Morton (1996) and Jansa et al. (2002) that a large part of AMF may not sporulate in the field at all or their sporulation is seasonal.

Frequency of occurrence of species. The species most frequently occurring in cultivated soils of the Lubuskie province were Gl. mosseae (present in $80.0 \%$ of soils) and Gl. claroideum (62.2\%; Tab. 1). Fungi relatively frequently recorded (present in $15-30 \%$ of soils) also were $G$ l. caledonium and $P$. franciscana. In uncultivated soils, the most frequently found fungi included Gl. constrictum $(51.1 \%)$ and Gl. claroideum (44.0\%), followed by Ac. lacunosa, Gl. macrocarpum, and S. dipurpurescens.

Dominance. The eudominants (of a coefficient of dominance of D>20\%) of cultivated sites were Gl. claroideum and Gl. deserticola (Tab. 2). The group of dominants $(\mathrm{D}=10-20 \%)$ formed only $G l$. mosseae. The subdominants $(\mathrm{D}=5-10 \%)$ were $\mathrm{Gl}$. caledonium, P. scintillans, and $S$. dipurpurescens. In uncultivated soils, the eudominants were Gl. constrictum and Gl. claroideum. Glomus badium, Gl. deserticola, Gl. lamel- 
Table 1

Frequency of occurrence of AMF isolated from under cultivated (a) and uncultivated (not protected) plants (b) of the Lubuskie province

\begin{tabular}{|c|c|c|c|c|c|c|}
\hline & \multicolumn{6}{|c|}{ Frequency of occurrence $(\%)$} \\
\hline \multirow[t]{3}{*}{ Fungus } & & & \multicolumn{4}{|c|}{ Trap cultures with } \\
\hline & \multicolumn{2}{|c|}{ Field soils } & \multicolumn{2}{|c|}{ P. lanceolata } & \multicolumn{2}{|c|}{ Z. mays } \\
\hline & $\mathrm{a}$ & $\mathrm{b}$ & a & $\mathrm{b}$ & $\mathrm{a}$ & $\mathrm{b}$ \\
\hline Acaulospora capsicula & & 5.56 & & & & \\
\hline Acaulospora lacunosa & & 16.67 & & & & \\
\hline Acaulospora koskei & & 1.11 & & & & \\
\hline Acaulospora mellea & & 4.44 & & & & \\
\hline Acaulospora paulinae & & 1.11 & & 1.11 & & \\
\hline Ambispora gerdemannii & & 13.33 & & & & 2.22 \\
\hline Archaeospora trappei & & & & 2.22 & 2.22 & 4.44 \\
\hline Entrophospora baltica & & 1.11 & & & & \\
\hline Entrophospora infrequens & & 1.11 & 5.56 & 3.33 & 4.44 & 2.22 \\
\hline Gigaspora gigantea & & 1.11 & & & & \\
\hline Gigaspora margarita & & 2.22 & & 4.44 & & 2.22 \\
\hline Gigaspora sp. & & & & & & 1.11 \\
\hline Glomus aggregatum & 5.56 & 10.00 & 3.33 & 11.11 & 2.22 & 2.22 \\
\hline Glomus badium & 1.11 & 8.89 & & 3.33 & & 1.11 \\
\hline Glomus caledonium & 17.78 & 5.56 & 37.8 & 10.00 & 30.00 & 17.78 \\
\hline Glomus claroideum & 27.78 & 20.00 & 56.7 & 44.44 & 62.22 & 40.00 \\
\hline Glomus clarum & & & & 5.56 & & \\
\hline Glomus constrictum & 28.89 & 51.11 & 11.1 & 26.7 & 1.11 & 8.89 \\
\hline Glomus deserticola & 24.44 & 25.56 & 15.6 & 10.00 & 1.11 & \\
\hline Glomus fasciculatum & 4.44 & 12.22 & 2.22 & 4.44 & 2.22 & \\
\hline Glomus fuegianum & & 1.11 & & & & \\
\hline Glomus geosporum & 3.33 & 5.56 & & & 2.22 & \\
\hline Glomus lamellosum & & & 1.11 & 7.78 & 1.11 & 6.67 \\
\hline Glomus macrocarpum & 8.89 & 16.67 & 1.11 & & & \\
\hline Glomus microcarpum & 1.11 & 6.67 & & 1.11 & & 1.11 \\
\hline Glomus mosseae & 80.00 & 26.67 & 61.1 & 31.11 & 60.00 & 25.56 \\
\hline Glomus pansihalos & & & & 1.11 & & \\
\hline Glomus pustulatum & & & & 1.11 & & 1.11 \\
\hline Glomus rubiforme & & 1.11 & & & & 1.11 \\
\hline Glomus verruculosum & & & 1.11 & & 2.22 & \\
\hline Glomus 178 & & & 3.33 & 4.44 & 2.22 & 7.78 \\
\hline Glomus sp. & & 1.11 & 1.11 & 2.22 & 1.11 & 2.22 \\
\hline Pacispora franciscana & 16.67 & 8.89 & 11.1 & 3.33 & 10.00 & $3 . .33$ \\
\hline Pacispora scintillans & 12.22 & 7.78 & 8.89 & 3.33 & 6.67 & 2.22 \\
\hline Paraglomus laccatum & & & & 1.11 & & 4.44 \\
\hline Scutellospora armeniaca & 1.11 & 1.11 & & & & 1.11 \\
\hline Scutellospora dipurpurescens & 8.89 & 23.33 & 8.89 & 17.78 & 5.56 & 14.44 \\
\hline Scutellospora pellucida & & 6.67 & & & & 5.56 \\
\hline Scutellospora $\mathrm{sp}$ & & 1.11 & & & & \\
\hline
\end{tabular}

losum and S. dipurpurescens were dominants, and E. infrequens, Gl. caledonium, and Gl. mosseae - subdominats.

The data presented above confirm Błaszkowski's (1993) and Gerdemann's (1968) conclusions that AMF are common soil fungi and coexist with most vascular cultivated and uncultivated plant species of the world.

The abundant and diverse spore populations of Glomus spp. revealed in the study discussed here indicate a good adaptation of these fungi to a wide range of soil conditions (Anderson, Liberta and Dickman 1984; Grey 1991; Jansa et al. 2002; Porter, Robson and Abbott 1987). Species of Gigaspora and Scutellospora prefer warmer 
Table 2

Dominance of AMF associated with cultivated (a) and uncultivated (b; not protected) plants of the Lubuskie province

\begin{tabular}{|c|c|c|c|c|c|c|}
\hline \multirow{4}{*}{ Fungus } & \multicolumn{6}{|c|}{ Dominance $(\%)$} \\
\hline & & & & Trap c & es with & \\
\hline & \multicolumn{2}{|c|}{ Field soils } & \multicolumn{2}{|c|}{ P. lanceolata } & \multicolumn{2}{|c|}{ Z. mays } \\
\hline & $\mathrm{a}$ & $\mathrm{b}$ & $\mathrm{a}$ & $\mathrm{b}$ & $\mathrm{a}$ & $\mathrm{b}$ \\
\hline & 1 & 2 & 3 & 4 & 5 & 6 \\
\hline Acaulospora capsicula & & 0.07 & & & & \\
\hline Acaulospora lacunosa & & 0.22 & & & & \\
\hline Acaulospora koskei & & 0.01 & & & & \\
\hline Acaulospora mellea & & 0.06 & & & & \\
\hline Acaulospora paulinae & & 0.01 & & 0.02 & & \\
\hline Ambispora gerdemannï & & 0.59 & & & & 0.09 \\
\hline Archaeospora trappei & & & & 2.33 & 0.42 & 1.50 \\
\hline Entrophospora baltica & & 0.01 & & & & \\
\hline Entrophospora infrequens & & 0.01 & 0.46 & 7.00 & 0.07 & 4.13 \\
\hline Gigaspora gigantea & & 0.03 & & & & \\
\hline Gigaspora margarita & & 0.06 & & 0.09 & & 0.09 \\
\hline Gigaspora sp. & & & & & & 0.06 \\
\hline Glomus aggregatum & 1.78 & 2.54 & 0.08 & 1.90 & 0.08 & 0.06 \\
\hline Glomus badium & 0.24 & 12.84 & & 1.90 & & 0.26 \\
\hline Glomus caledonium & 2.17 & 0.27 & 2.47 & 6.04 & 8.74 & 2.34 \\
\hline Glomus claroideum & 4.10 & 3.10 & 67.44 & 27.37 & 66.00 & 56.72 \\
\hline Glomus clarum & & & & 3.29 & & \\
\hline Glomus constrictum & 4.43 & 32.91 & 0.17 & 4.01 & 0.12 & 2.17 \\
\hline Glomus deserticola & 53.47 & 17.04 & 6.07 & 5.53 & 0.01 & \\
\hline Glomus fasciculatum & 0.20 & 1.23 & 0.02 & 0.22 & 0.03 & \\
\hline Glomus fuegianum & & 2.81 & & & & \\
\hline Glomus geosporum & 0.59 & 0.25 & & & 0.42 & \\
\hline Glomus lamellosum & & & 0.07 & 10.43 & 0.04 & 13.15 \\
\hline Glomus macrocarpum & 0.35 & 4.23 & 0.02 & & & \\
\hline Glomus microcarpum & 0.11 & 4.27 & & 2.86 & & 0.03 \\
\hline Glomus mosseae & 17.64 & 3.10 & 10.59 & 4.60 & 15.00 & 8.49 \\
\hline Glomus pansihalos & & & & 0.07 & & \\
\hline Glomus pustulatum & & & & 0.16 & & 0.49 \\
\hline Glomus rubiforme & & 3.16 & & & & 1.10 \\
\hline Glomus verruculosum & & & 0.01 & & 0.15 & \\
\hline Glomus 178 & & & 0.46 & 0.75 & 2.45 & 0.84 \\
\hline Glomus sp. & & 0.03 & 0.15 & 2.11 & 0.03 & 0.06 \\
\hline Pacispora franciscana & 4.67 & 0.79 & 3.27 & 0.84 & 4.01 & 0.32 \\
\hline Pacispora scintillans & 5.90 & 0.46 & 2.40 & 1.24 & 0.60 & 0.17 \\
\hline Paraglomus laccatum & & & & 0.02 & & 4.33 \\
\hline Scutellospora armeniaca & 0.07 & 0.04 & & & & 0.75 \\
\hline $\begin{array}{l}\text { Scutellospora } \\
\text { dipurpurescens }\end{array}$ & 4.30 & 7.36 & 6.30 & 17.23 & 1.83 & 2.40 \\
\hline Scutellospora pellucida & & 2.25 & & & & 0.46 \\
\hline Scutellospora sp. & & 0.22 & & & & \\
\hline
\end{tabular}

(Koske 1981; Schenck, Graham and Green 1975) and more sandy soils (Błaszkowski 1993b).

Spore density. The overall mean spore density of AMF in field soils collected under cultivated plants was 50.7 and ranged from 0 to 925 spores in $100 \mathrm{~g}$ dry soil. In the rhizosphere of uncultivated plants, the values were 77.3 and 0 to 865 in $100 \mathrm{~g}$ dry soil, respectively.

Most spores were isolated from under Beta vulgaris, Hypericum perforatum, Polygonum persicaria, and Trifolium arvense (Tabs 3 and 4). 
Table 3

Spore abundance and species richness of AMF associated with roots of 10 cultivated plant species (means)

\begin{tabular}{|l|c|c|c|c|}
\hline \multirow{2}{*}{ Plant species } & $\begin{array}{c}\text { Spore } \\
\text { abundance }\end{array}$ & \multicolumn{2}{|c|}{ Species richness } \\
\cline { 2 - 5 } & Field soils* & \multirow{2}{*}{ Field soils* } & \multicolumn{2}{c|}{ Trap cultures with** } \\
\cline { 3 - 5 } & & & P. lanceolata & Z. mays \\
\hline Asparagus officinalis & 11.00 & 2.00 & 1.78 & 1.78 \\
\hline Avena sativa & 46.89 & 2.56 & 2.33 & 2.22 \\
\hline Beta vulgaris & 119.00 & 2.56 & 2.89 & 2.00 \\
\hline Brassica napus & 32.25 & 2.56 & 1.69 & 1.78 \\
\hline Hordeum vulgare & 35.00 & 2.78 & 2.56 & 2.58 \\
\hline Secale cereale & 54.67 & 3.22 & 1.89 & 2.20 \\
\hline Solanum tuberosum & 15.11 & 1.78 & 2.56 & 1.56 \\
\hline Triticum aestivum & 102.78 & 2.44 & 2.33 & 1.86 \\
\hline XTriticum secalum & 19.00 & 1.89 & 2.50 & 1.67 \\
\hline Zea mays & 46.67 & 2.67 & 2.78 & \\
\hline
\end{tabular}

$*$ in $100 \mathrm{~g}$ dry soil ** in $50 \mathrm{~g}$ dry soil

Table 4

Spore abundance and species richness of AMF associated with roots of 15 uncultivated (not protected) plant species (means)

\begin{tabular}{|l|c|c|c|c|}
\hline \multirow{2}{*}{ Plant species } & $\begin{array}{c}\text { Spore } \\
\text { abundance }\end{array}$ & \multicolumn{3}{|c|}{ Species richness } \\
\cline { 2 - 5 } & Field soils* & \multirow{2}{*}{ Field soils* } & \multicolumn{2}{c|}{ Trap cultures with** } \\
\cline { 3 - 5 } & & & P. lanceolata & Z. mays \\
\hline Achillea millefolium & 121.33 & 3.00 & 2.33 & 1.67 \\
\hline Carex sylvatica & 10.00 & 2.17 & 1.67 & 1.60 \\
\hline Cirsium arvense & 87.33 & 4.00 & 3.50 & 2.33 \\
\hline Corynephorus canescens & 6.00 & 1.17 & 1.33 & 0.17 \\
\hline Equisetum arvense & 67.17 & 3.67 & 0.67 & 2.00 \\
\hline Hypericum perforatum & 149.00 & 3.17 & 1.33 & 1.83 \\
\hline Juncus effusus & 10.33 & 1.33 & 1.17 & 1.67 \\
\hline Melandrium album & 144.50 & 3.83 & 2.50 & 1.67 \\
\hline Plantago arenaria & 30.00 & 2.00 & 1.83 & 2.50 \\
\hline Plantago lanceolata & 55.83 & 2.83 & 2.67 & 1.80 \\
\hline Polygonum persicaria & 181.17 & 2.33 & 2.17 & 1.50 \\
\hline Potentilla anserina & 12.40 & 2.17 & 1.50 & 0.00 \\
\hline Rumex acetosella & 34.83 & 3.00 & 1.50 & 1.17 \\
\hline Sedum maximum & 35.25 & 2.33 & 2.00 & 2.00 \\
\hline Trifolium arvense & 277.00 & 2.50 & 2.50 & 2.17 \\
\hline
\end{tabular}

$*$ in $100 \mathrm{~g}$ dry soil ** in $50 \mathrm{~g}$ dry soil

Species density. The overall mean species density of AMF in field soils from under cultivated plants was 2.44 and ranged from 0 to 7 in $100 \mathrm{~g}$ dry soil. The mean species density of AMF associated with uncultivated plant was 2.63 within the range 0-6 in $100 \mathrm{~g}$ dry soil. In trap cultures with soils and roots of cultivated plants and the host plants $P$. lanceolata and $Z$. mays, the overall mean species density was higher by $12.4 \%$ and $19.1 \%$, respectively, than in those with soils and roots of uncultivated plants (Tabs 3 and 4).

In the field, of the cultivated plants, most species were harboured by Secale cereale, and of uncultivated plants - Cirsium arvense, Equisetum arvense and Melandrium 
album (Tabs 3 and 4). In trap cultures representing cultivated plants, most species were found when the growing media were soil-root samples from under B. vulgaris and Z. mays (Tab. 3). When trap cultures contained soils and roots from under uncultivated plants, most species came from those representing $C i$. arvense (Tab. 4).

The species most frequently revealed in the spore populations of AMF associated with roots of cultivated and uncultivated plants of the Lubuskie province, i.e., Gl. claroideum, Gl. constrictum, Gl. deserticola, Gl. mosseae and S. dipurpurescens, have many times been found in cultivated and uncultivated sites of different regions of the world (Błaszkowski 1993a; Jansa et al. 2002).

Literature data on the sporulation of AMF in cultivated versus uncultivated soils are contradictory. As found in this study and that of Błaszkowski (1993a), AMF produced more spores in uncultivated soils, probably because of the lack of inhibitory influences of agricultural practices. According to Oehl et al. (2005), intensive agricultural farming decreases spore production and the numbers of species, especially those from the genus Glomus. In contrast, Jansa et al. (2002) concluded that some taxa of AMF are activated in conditions of agricultural soils. The over 2-fold higher frequency of occurrence of $S$. dipurpurescens in uncultivated soils probably resulted from high sensitivity of this species to agricultural practices. Spores of Scutellospora spp. generally are much larger than those of other AMF and easier undergo destructions (Błaszkowski 2003).

Arbuscular mycorrhizae. The occurrence of arbuscular mycorrhizae (AM) in this group of plants was determined based on 75 root samples. Each plant species was represented by three root samples.

Arbuscules. Of cultivated plants, the highest levels of root colonization by arbuscules were found in $S$. cereale and $Z$. mays (Tab. 5). In wild plants, most arbuscules occurred in roots of Hy. perforatum, Plantago arenaria, and P. lanceolata. No arbuscules were found in roots of the cultivated Brassica napus, B. vulgaris and Solanum tuberosum and the uncultivated Carex sylvatica, E. arvense, and Pol. persicaria.

Vesicles. Of the 10 cultivated plant species, only roots of Ho. vulgare and Z. mays contained a high number of vesicles (Tab. 5). Of the wild plants, most vesicles were found in roots of $P$. arenaria, $P$. lanceolata, and Sedum maximum.

Intraradical hyphae. Most intraradical hyphae had roots of the cultivated Hordeum vulgare and $Z$. mays and the wild Hy. perforatum and Sed. maximum (Tab. 5). No intraradical hyphae were revealed in roots of $B$. vulgare, Br. napus, C. sylvatica, E. arvense, and So. tuberosum.

According to Sanders et al. (1977), already a $10 \%$ level of root colonization by AMF significantly increases the absorption of $\mathrm{P}$ from the soil. Volkmar and Woodbury (1989) found that 2-7\% colonization of roots by AMF increased up to $25 \%$ the shot weight of Ho. vulgare.

The presence of arbuscules indicates a functional AM (Smith, Read 2008). However, arbuscules were not found in roots of $B$. vulgaris sampled in this study, which, on the other hand, harboured abundant spore populations of AMF. Intraradical components of AM of many species of the Glomeromycota either stain faintly or not at all and, thereby, may be omitted (Stutz, Morton 1996). In the literature, the amount of data on the active functioning of AM in roots of members of the family Chenopodiaceae increases (Landwehr et al. 2002). 
Table 5

Mean percent of root length of cultivated and uncultivated (not protected) plants of the Lubuskie province with arbuscules, vesicles, and intraradical hyphae of AMF

\begin{tabular}{|l|c|c|c|}
\hline Plant species & Arbuscules & Vesicles & Hyphae \\
\hline Asparagus officinalis & \multicolumn{3}{|c|}{ Cultivated plants } \\
\hline Avena sativa & 5.00 & 8.00 & 25.00 \\
\hline Beta vulgaris & 3.00 & 5.00 & 46.0 \\
\hline Brassica napus & 0.00 & 0.00 & 0.00 \\
\hline Hordeum vulgare & 0.00 & 0.00 & 0.00 \\
\hline Secale cereale & 18.00 & 22.00 & 59.00 \\
\hline Solanum tuberosum & 32.00 & 1.00 & 53.00 \\
\hline Triticum aestivum & 0.00 & 0.00 & 0.00 \\
\hline XTriticum aestivum & 5.00 & 9.00 & 53.00 \\
\hline Zea mays & 3.00 & 17.00 & 51.00 \\
\hline & 38.00 & 20.00 & 66.00 \\
\hline Achillea millefolium & \multicolumn{3}{|c|}{ Uncultivated plants } \\
\hline Carex sylvatica & 7.00 & 20.00 & 50.00 \\
\hline Cirsium arvense & 0.00 & 0.00 & 0.00 \\
\hline Corynephorus canescens & 19.00 & 9.00 & 15.00 \\
\hline Equisetum arvense & 5.00 & 10.00 & 40.00 \\
\hline Hypericum perforatum & 0.00 & 0.00 & 0.00 \\
\hline Juncus effusus & 27.00 & 21.00 & 65.00 \\
\hline Melandrium album & 5.00 & 15.00 & 42.00 \\
\hline Sedum maximum & 1.00 & 12.00 & 49.00 \\
\hline Plantago arenaria & 1.00 & 24.00 & 66.00 \\
\hline Plantago lanceolata & 28.00 & 40.00 & 42.00 \\
\hline Polygonum persicaria & 31.00 & 31.00 & 22.00 \\
\hline Potentilla anserina & 0.00 & 1.00 & 49.00 \\
\hline Rumex acetosella & 2.00 & 18.00 & 51.00 \\
\hline Trifolium arvense & 4.00 & 4.00 & 22.00 \\
\hline & 1.00 & 8.00 & 53.00 \\
\hline \multicolumn{3}{|c|}{} \\
\hline
\end{tabular}

\section{ARBUSCULAR MYCORRHIZAL FUNGI AND ARBUSCULAR MYCORRHIZAE ASSOCIATED WITH PROTECTED PLANTS}

Arbuscular mycorrhizal fungi. The occurrence of AMF associated with protected plants was determined based 48 rhizosphere soil-root samples collected under 6 plant species being fully or partly protected (Fig. 1). Each plant species was represented by 8 soil-root mixtures sampled at four sites of the Lagowo Landscape Park located in Łagowo and at two sites of the Pszczewo Landscape Park positioned in Trzciel (Fig. 1).

Spores of AMF occurred in $31.2 \%$ of soil-root samples. They belonged to 11 species of Glomus, two species each of Acaulospora and Scutellospora, one species each of Ambispora, Archaeospora and Pacispora, two undescribed morphotypes (one each of Glomus and Scutellospora), and not numerous spores of unrecognized fungi forming glomoid spores (Tab. 6).

AMF sporulated in 29 trap cultures with P. lanceolata as the host plant, i.e., $60.4 \%$ of all trap cultures established. The spores represented 12 species and two undescribed morphotypes (one each of Glomus and Scutellospora; Tab. 6).

Frequency of occurrence of species. The species of AMF most frequently cooccurring with roots of protected plants (present in $>18 \%$ of samples and trap cultures) were Gl. claroideum, Gl. constrictum, and S. dipurpurescens (Tab. 6). 
Table 6

Frequency of occurrence and dominance of AMF associated with roots of protected plant species

\begin{tabular}{|c|c|c|c|c|}
\hline \multirow[b]{2}{*}{ Fungus } & \multicolumn{2}{|c|}{ Frequency of occurrence $(\%)$} & \multicolumn{2}{|c|}{ Dominance } \\
\hline & Field soils & $\begin{array}{l}\text { Trap cultures } \\
\text { with } P \text {. } \\
\text { lanceolata }\end{array}$ & Field soils & $\begin{array}{c}\text { Trap cultures } \\
\text { with } P \text {. } \\
\text { lanceolata }\end{array}$ \\
\hline Acaulospora lacunosa & 6.25 & & 17.86 & \\
\hline Acaulospora mellea & & 2.08 & & 0.03 \\
\hline Ambispora gerdemannii & 2.08 & & 0.30 & \\
\hline Archaeospora trappei & & 6.25 & & 0.62 \\
\hline Glomus aggregatum & & 2.08 & & 0.03 \\
\hline Glomus badium & 2.08 & & 29.76 & \\
\hline Glomus claroideum & 4.17 & 20.83 & 2.38 & 79.29 \\
\hline Glomus constrictum & 18.75 & 2.08 & 24.11 & 0.03 \\
\hline Glomus geosporum & 2.08 & & 0.30 & \\
\hline Glomus lamellosum & & 12.50 & & 5.27 \\
\hline Glomus macrocarpum & & 2.08 & & 0.03 \\
\hline Glomus microaggregatum & 2.08 & & 2.98 & \\
\hline Glomus microcarpum & 4.17 & & 16.67 & \\
\hline Glomus mosseae & 6.25 & 6.25 & 1.49 & 1.46 \\
\hline Glomus verruculosum & & 2.08 & & 0.03 \\
\hline Glomus 178 & & 2.08 & & 0.35 \\
\hline Glomus sp. & & 6.25 & & 6.24 \\
\hline Paraglomus laccatum & & 8.33 & & 2.29 \\
\hline $\begin{array}{l}\text { Scutellospora } \\
\text { dipurpurescens }\end{array}$ & 4.17 & 20.83 & 2.68 & 3.78 \\
\hline Scutellospora pellucida & 2.08 & 4.17 & 1.49 & 0.49 \\
\hline Scutellospora 179 & & 2.08 & & 0.03 \\
\hline
\end{tabular}

Dominance. The eudominants (D>20\%) were Gl. badium and Gl. constrictum (Tab. 6). The group of dominants $(\mathrm{D}=10-20 \%)$ formed A. lacunosa and Gl. microcarpum. None of the other species found was a subdominant $(\mathrm{D}=5-10 \%)$.

Spore density. The overall mean spore density of AMF in field soils was 7.00 and ranged from 0 to 100 spores in $100 \mathrm{~g}$ dry soil. Most spores were associated with roots of Jovibarba sobolifera, and least with those of Lycopodium clavatum (Tab. 7).

Species density. The plant species harbouring most species was $J$. sobolifera (Tab. 7). Relatively high numbers of species were also associated with roots of Convalaria majalis and L. clavatum.

In Zubek's et al. (2005) investigations, the overall mean species richness of AMF co-existing with protected plants of the Mountain Botanical Garden in Zakopane

Table 7

Spore abundance and species richness of AMF associated with roots of six protected plant species in field soils (a) and trap cultures with $P$. lanceolata as the host plant (b; means)

\begin{tabular}{|l|c|c|c|c|}
\hline & \multicolumn{2}{|c|}{ Spore abundance } & \multicolumn{2}{c|}{ Species richness } \\
\hline Plant species & $\mathrm{a}$ & $\mathrm{b}$ & $\mathrm{a}$ & $\mathrm{b}$ \\
\hline Convallaria majalis & 12.5 & 207.9 & 0.13 & 1.1 \\
\hline Hedera helix & 1.0 & 19.9 & 0.50 & 0.7 \\
\hline Helichrysum arenarium & 7.2 & 16.4 & 0.25 & 0.7 \\
\hline Jovibarba sobolifera & 17.5 & 16.2 & 1.13 & 1.2 \\
\hline Lycopodium clavatum & 0.6 & 30.2 & 0.38 & 1.0 \\
\hline Vinca minor & 3.1 & 69.7 & 0.87 & 0.6 \\
\hline
\end{tabular}


Table 8

Mean percent of root length of protected plants of the Lubuskie province with arbuscules, vesicles, and intraradical hyphae of AMF

\begin{tabular}{|l|c|c|c|}
\hline Plant species & Arbuscules & Vesicles & Hyphae \\
\hline Convallaria majalis & 29.00 & 8.00 & 60.00 \\
\hline Hedera helix & 0.00 & 0.00 & 0.00 \\
\hline Helichrysum arenarium & 29.00 & 31.00 & 50.00 \\
\hline Jovibarba sobolifera & 19.00 & 23.00 & 52.00 \\
\hline Lycopodium clavatum & 0.00 & 0.00 & 0.00 \\
\hline Vinca minor & 1.00 & 22.00 & 54.00 \\
\hline
\end{tabular}

was higher than that found in this study. However, in both investigations the species most frequently identified were Gl. claroideum and Gl. constrictum.

Arbuscular mycorrhizae.The occurrence of AM of protected plants of the Lubuskie province was determined based on 18 roots samples from six plant species. Each plant species was represented by three samples.

Arbuscules. The highest levels of root colonization by arbuscules were found in Con. majalis and Helichrysum arenarium (Tab. 8). No arbuscules were found in roots of Hedera helix and L. clavatum.

Vesicles. Most vesicles were found in roots of Hel. arenarium, then in those of $J$. sobolifera and Vinca minor (Tab. 8).

Intraradical hyphae. The plant species harbouring most intraradical hyphae was Con. majlis (Tab. 8). No intraradical hyphae were observed in roots of $H$. helix and L. clavatum.

\section{THE OCCURRENCE OF SPORES OF AMF vS. AM vS. IN CONNECTION WITH SOIL CHEMICAL PROPERTIES}

Soil $\mathrm{pH}$ ranged from 3.67 to 8.28 . The ranges of the total contents $\left(\mathrm{g}^{\mathrm{kg}} \mathrm{kg}^{-1}\right.$ of dry matter) of organic $\mathrm{C}, \mathrm{N}, \mathrm{P}$, and $\mathrm{K}$ were $0.42-2.0,0.30-22.5,0.13-2.02$, and $0.10-4.63$, respectively. The values of available forms of $\mathrm{P}, \mathrm{K}$, and $\mathrm{Mg}\left(\mathrm{g} \mathrm{kg}^{-1}\right.$ of dry matter) ranged 9.4-361, 4.90-327, and 13.4-98.8, respectively.

Rectilinear correlation analyses showed that the spore numbers of AMF associated with roots of wild plants significantly correlated with the contents of organic $\mathrm{C}(\mathrm{r}=0.38$; $\mathrm{P}, 0.005)$ and available $\mathrm{Mg}(\mathrm{r}=0.55 ; \mathrm{P}<0.05)$. The contents of total $(\mathrm{r}=0.50 ; \mathrm{P}<0.005)$ and available $\mathrm{K}(\mathrm{r}=0.43 ; \mathrm{P}<0.05)$ in soils from under cultivated plants influenced the abundance of $G l$. mosseae spores. The contents of available $\mathrm{Mg}$ in soils of cultivated sites was linked with the numbers of $G$ l. claroideum spores $(\mathrm{r}=0.90 ; \mathrm{P}<0.05)$. In uncultivated soils, the contents of organic $\mathrm{C}$ and total $\mathrm{N}$ and $\mathrm{Mg}$ correlated with numbers of $\mathrm{Gl}$. constrictum spores: $\mathrm{r}=0.66, \mathrm{P}<0.05 ; \mathrm{r}=0.59, \mathrm{P}<0.05$; and $\mathrm{r}=0.62, \mathrm{P}<0.05$, respectively.

The levels of mycorrhizal colonization did not correlate with any of the soil chemical properties considered. Insignificant also were correlations between numbers of spores and species and levels of mycorrhizal colonization.

The results of our study contradict those of many workers who proved that higher contents of soil $\mathrm{P}$ generally decrease the production of spores by AMF and the composition and distribution of structures of AM inside roots (Smith, Read 1990). Alternatively, the activity of AMF did not correlate with soil P because of its changing availability at different levels of $\mathrm{pH}$ (Hayman 1970). 
The lack of relationships between the level of mycorrhizal colonization and the spore abundance and the species richness may have resulted from that the stains used did not reveal structures of all AMF in reality existing inside roots (Morton, Redecker 2001).

Acknowledgements. This study was supported in part by the Polish Committee of Scientific Researches, grants no. 164/N-COST/2008/0 and N N304 061739.

\section{REFERENCES}

Anderson R. C., Liberta A. E., Dickman L. A. 1984 Interaction of vascular plants and vesicular-arbuscular mycorrhizal fungi across a soil moisture-nutrient gradient. Oceologia 64: 111-117.

Bever J., Morton J. B., Antonovics J., Schultz P. A. 1996. Host-dependent sporulation and species diversity of arbuscular mycorrhizal fungi in a mown grassland. J. Ecol. 84: 71-82.

Błaszkowski J. 1988. Four new species of the Endogonaceae (Zygomycotina) from Poland. Karstenia 27: $37-42$.

Błaszkowski J. 1993a. Comparative studies of the occurrence of arbuscular fungi and mycorrhizae (Glomales) in cultivated and uncultivated soils of Poland. Acta Mycol. 28: 93-140.

Błaszkowski J. 1993b. The occurrence of arbuscular fungi and mycorrhizae (Glomales) in plant communities of maritime dunes and shores of Poland. Bull. Pol. Ac. Sci. Biol. Sci. 41: 377-392.

Błaszkowski J. 2003. Arbuscular mycorrhizal fungi (Glomeromycota), Endogone and Complexipes species deposited in the Department of Plant Pathology, University of Agriculture in Szczecin, Poland. http://www.agro.ar.szczecin.pl/ jblaszkowski/.

Błaszkowski J., Kovács G.M., Balázs T. 2009. Glomus perpusillum, a new arbuscular mycorrhizal fungus. Mycologia 101: 247-255.

Błaszkowski J., Renker C., Buscot F. 2006. Glomus drummondii and G. walkeri, two new species of arbuscular mycorrhizal fungi (Glomeromycota). Mycol. Res. 110: 555-566.

Błaszkowski J., Ryszka P., Oehl F., Koegel S., Wiemken A., Kovács G. M., Redecker D. 2009. Glomus achrum and G. bistratum, two new species of arbuscular mycorrhizal fungi (Glomeromycota) found in maritime sand dunes. Botany 87: 260-271.

Błaszkowski J., Tadych M., Madej M. 2000. Glomus minutum, a new species in Glomales (Zygomycetes) from Poland. Mycotaxon 76: 187-195.

Błaszkowski J., Tadych M., Madej T. 2002. Arbuscular mycorrhizal fungi (Glomales, Zygomycota) of the Błędowska Desert. Acta Soc. Bot. Pol. 71: 71-85.

Gerdemann J. W. 1968. Vesicular-arbuscular mycorrhiza and plant growth. Annu. Rev. Phytopath. 6: 397-418.

Górny M., Gruma L. 1981. Metody stosowane w zoologii gleby. PWN, Warszawa.

Grey W. E. 1991. Influence of temperature on colonization of spring barleys by vesicular-arbuscular mycorrhizal fungi. Plant and Soil 137: 181-190.

Jansa J., Mozafar A., Anken T., Ruh R., Sanders I. R., Frossard E. 2002. Diversity and structure of AMF communities as affected by tillage in a temperate soil. Mycorrhiza 12: 225-234.

Kaczorowska Z. 1962. Opady w Polsce w przekroju wieloletnim. Prace Geogr. IG PAN 33:1-107.

Klironomos J. N., McCune J., Hart M., Neville J. 2000. The influence of arbuscular mycorrhizae on the relationship between plant diversity and productivity. Ecol. Lett. 3: 137-141.

Koske R. E. 1981. A preliminary study of interactions between species of vesicular-arbuscular mycorrhizal fungi in a sand dune. Trans. Br. Mycol. Soc. 76: 411-416.

Koske R. E., Gemma J. N., Corkidi L., Sigüenza C., Rinkón E. 2004. Arbuscular mycorrhizas in coastal dunes. (In:) M. I. Martínez, N. P. Psuty (eds). Coastal dunes, ecology and conservation. Ecol. Stud. 171: $173-187$.

Koske R. E., Polson W. R. 1984. Are VA mycorrhizae required for sand stabilization? Bioscience 34: 420-424.

Landwehr M., Hildebrandt U., Wilde P., Nawrath K., Tóth T., Biró B., Bothe H. 2002. The arbuscular mycorrhizal fungus Glomus geosporum in European saline, sodic and gypsum soils. Mycorrhiza 12: 199-211. 
Morton J. B. 2002. International Culture Collection of Arbuscular and Vesicular-Arbuscular Mycorrhizal Fungi. West Virginia University: http://www.invam.caf.wvu.edu/.

Morton J. B., Redecker D. 2001. Two families of Glomales, Archaeosporaceae and Paraglomaceae, with two new genera Archaeospora and Paraglomus, based on concordant molecular and morphological characters. Mycologia 93: 181-195.

Oehl F., Sieverding E. 2004. Pacispora, a new vesicular arbuscular mycorrhizal fungal genus in the Glomeromycetes. J. Appl. Bot. 78: 72-82.

Oehl F., Sieverding E., Ineichen K., Mäder P., Wiemken A., Boller T. 2009. Distinct sporulation dynamics of arbuscular mycorrhizal fungal communities from different agroecosystems in long-term microcosms. Agric., Ecosystems, Environment 134: 257-268.

Oehl F., Sieverding E., Ineichen K., Ris E.-A., Boller T., Wiemken A. 2005. Community structure of arbuscular mycorrhizal fungi at different soil depths in extensively and intensively managed agroecosystems. New Phytol. 165: 273-283.

Omar M. B., Bollan L., Heather W. A. 1979. A permanent mounting medium for fungi. Bull. Br. Mycol. Soc. 13: 31-32.

Öpik M., Metsis M., Daniell T. J, Zobel M., Moora M. 2009. Large-scale parallel 454 sequencing reveals host ecological group specificity of arbuscular mycorrhizal fungi in a boreonemoral forest. New Phytol 184: 424-437.

Palenzuela J., Ferrol N., Boller T., Azcón-Aguilar C., Oehl F. 2008. Otospora bareai, a new fungal species in the Glomeromycetes from a dolomitic shrubland in the Natural Park of Sierra de Baza (Granada, Spain). Mycologia 100: 296-305.

Porter W. M., Robson A. D., Abbott L. K. 1987. Field survey of the distribution of vesicular-arbuscular mycorrhizal fungi in relation to soil pH. J. Appl. Ecol. 24: 659-662.

Sanders F. E., Tinker P. B., Black R. L. B., Palmersley S. M. 1977. The development of endomycorrhizal root systems. I. Spread of infection and growth-promoting effects with four species of vesiculararbuscular endophytes. New Phytol. 77: 257-268.

Schenck N. C., Graham S. O., Green N. E., 1975. Temperature and light effects on contamination and spore germination of vesicular-arbuscular mycorrhizal fungi. Mycologia 57: 1189-1194.

Schönbeck F. 1978. Einfluss der endotrophen Mykorrhiza auf die Krankheitsresistenz höherer Pflanzen. Z. Pflkrankh. Pflschutz. 85: 191-196.

Schüßler A., Schwarzott D., Walker C. 2001. A new fungal phylum, the Glomeromycota: phylogeny and evolution. Myc. Res. 105: 1413-1421.

Sieverding E., Oehl F. 2006. Revision of Entrophospora and description of Kuklospora and Intraspora, two new genera in the arbuscular mycorrhizal Glomeromycetes. J. Appl. Bot. Food Qual. 80: 69-81.

Smith S. E., Read D. J. 2008. Mycorrhizal symbiosis. 3rd ed. Academic Press: Harcourt Brace \& Company, Publishers. San Diego, London, New York, Boston, Sydney, Tokyo, Toronto.

Stutz J. C., Morton J. B. 1996. Successive pot cultures reveal high species richness of arbuscular mycorrhizal fungi in arid ecosystems. Can. J. Bot. 74: 1883-1889.

Volkmar K. M., Woodbury W. 1989. Effects of soil temperature and depth on colonization and root and shoot growth of barley inoculated with vesicular-arbuscular mycorrhizae indigenous to Canadian prairie soil. Can. J. Bot. 67: 1702-1707.

Walker C., Vestberg M., Demircik F., Stockinger H., Saito M., Sawaki H., Nishmura I., Schüßler A. 2007. Molecular phylogeny and new taxa in the Archaeosporales (Glomeromycota): Ambispora fennica gen. sp. nov., Ambisporaceae fam. nov., and emendation of Archaeospora and Archaeosporaceae. Mycol. Res. 111: 137-153.

Zubek Sz., Turnau K., Błaszkowski J. 2005. Arbuscular mycorrhiza of plants from the Mountain Botanical Garden in Zakopane. Acta Mycol. 40 (1): 25-41. 


\section{Arbuskularne grzyby mikoryzowe (Glomeromycota) związane z korzeniami roślin województwa lubuskiego}

\section{Streszczenie}

Przedstawiono i przedyskutowano wyniki badań występowania arbuskularnych grzybów mikoryzowych (AGM) i mikoryz arbuskularnych z gromady Glomeromycota związanych z korzeniami 31 gatunków roślin uprawnych, nieuprawnych i chronionych rosnących w 103 stanowiskach województwa lubuskiego. Najczęściej znajdywanymi AGM byli przedstawiciele rodzaju Glomus. Często ujawniano również gatunki z rodzaju Scutellospora. Populacje zarodników AGM na ogół były bardziej obfite i różnorodne w glebach uprawnych. Większość gatunków roślin chronionych utrzymywała AGM. 